\title{
Morphophysiology and nutrition of yellow passion fruit seedlings grown in substrates based on carnaúba palm bagana
}

\author{
Andreza de Melo Mendonça ${ }^{1 *} \mathbb{\oplus}$, William Natale ${ }^{1} \odot$, \\ Geocleber Gomes de Sousa², Francisco Barroso da Silva Junior ${ }^{1}[0$ \\ ${ }^{1}$ Universidade Federal do Ceará, Fortaleza, CE, Brasil. E-mail: andreza.melo2911@gmail.com; natale@ufc.br; juniorbarroso_99@hotmail.com \\ ${ }^{2}$ Universidade da Integração Internacional da Lusofonia Afro-Brasileira, Redenção, CE, Brasil. E-mail: sousagg@unilab.edu.br
}

ABSTRACT: The use of agro-industrial waste may represent an alternative to reduce the costs of purchasing commercial substrates by producers of passion fruit seedlings, and carnaúba palm bagana is an alternative for the Northeastern Brazilian region. In this context, the objective was to evaluate the production of yellow passion fruit seedlings in substrates based on carnaúba bagana in different proportions with soil. The experiment was conducted in the experimental area of the Agrometeorological Station of Fortaleza, Pici Campus, Federal University of Ceará, Brazil, in a completely randomized design, whose treatments consisted of substrates formulated from the combination of different proportions of carnaúba bagana (CB) and soil: Soil (100\%) + CB (0\%); Soil $(75 \%)+$ CB (25\%); Soil $(50 \%)+$ CB (50\%); Soil $(25 \%)+$ CB $(75 \%)$; and Soil $(0 \%)+$ CB $(100 \%)$. The presence of CB, regardless of its proportion in the substrate, leads to the best results in photosynthesis and Dickson quality index (DQI) in yellow passion fruit seedlings. The best morphological responses were obtained with CB proportions greater than $50 \%$, which also led to greater accumulation of nutrients in the shoots.

Key words: agro-industrial waste; mineral elements; Passiflora edulis f. flavicarpa

\section{Morfofisiologia e nutrição de mudas de maracujazeiro-amarelo cultivado em substratos à base de bagana de carnaúba}

RESUMO: O emprego de resíduos agroindustriais pode representar uma alternativa para diminuir os custos de aquisição de substratos comerciais pelos produtores de mudas de maracujazeiro, sendo a bagana de carnaúba uma alternativa para a região do Nordeste brasileiro. Nesse contexto, objetivou-se avaliar a produção de mudas de maracujazeiro-amarelo em substratos à base de bagana de carnaúba em diferentes proporções com o solo. 0 experimento foi conduzido na área experimental da Estação Agrometeorológica de Fortaleza, Campus do Pici, Universidade Federal do Ceará, Brasil, em delineamento inteiramente casualizado, cujo os tratamentos foram constituídos por substratos formulados a partir da combinação de diferentes proporções de bagana de carnaúba (BC) e solo: Solo $(100 \%)+$ BC (0\%); Solo $(75 \%)+$ BC $(25 \%)$; Solo $(50 \%)+$ BC $(50 \%)$; Solo $(25 \%)$ + BC (75\%); e Solo (0\%) + BC (100\%). A presença de BC, independentemente de sua proporção no substrato, apresenta os melhores resultados na fotossíntese e no índice de qualidade de Dickson (IQD) em mudas de maracujazeiro amarelo. As melhores respostas morfológicas foram obtidas nas proporções maiores que $50 \%$ de BC, que levou também ao maior acúmulo de nutrientes na parte aérea.

Palavras-chave: resíduo agroindustrial; elementos minerais; Passiflora edulis f. flavicarpa

\footnotetext{
*Andreza de Melo Mendonça - E-mail: andreza.melo2911@gmail.com (Corresponding author)

Associate Editor: Sérgio Ruffo Roberto
} 


\section{Introduction}

Brazil is one of the world's largest fruit producers, due to its soil and climate characteristics for the development of fruit growing (Natale et al., 2012). In addition, the activity has economic and social advantages, since it contributes to keeping rural workers in the field, improves the distribution of regional income, and generates products of high commercial value, contributing to a great monetary movement in the country.

Passion fruit (Passiflora edulis f. flavicarpa) is gaining increasing prominence in the national scene, as this fruit crop has become increasingly cultivated for being a source of income for small and medium farmers, due to the demand of agroindustry for the production of juices, food and cosmetics, in addition to providing rapid economic return to producers (Junghans \& Jesus, 2017).

According to data of IBGE (2019), passion fruit is cultivated in the entire Brazilian territory, consolidating the country as the world's first producer of the fruit, with the Northeast region being the main producer.

Seedling production is one of the aspects that must be taken into account and that can influence the production potential of the orchard and, consequently, the obtaining of quality fruits. At this stage, it is important to investigate the substrates used, regarding the physicochemical properties and supply of nutrients (Natale et al., 2018).

The replacement of mineral fertilizer, which is more expensive, with organic residues in the formulation of substrates for seedling production has been growing in the scientific environment. That is, these compounds represent an alternative to reduce the costs of purchasing commercial substrates by producers, as well as contributing to the reduction of incorrect disposal of agro-industrial waste (Siqueira et al., 2020). In this context, an alternative would be the use of carnaúba palm (Copernicia prunifera) bagana, a by-product derived from the extraction of wax from carnaúba palm leaves, since there are already promising results for some crops, such as 'Formosa' papaya (Albano et al., 2017), for which bagana promoted the formation of good quality seedlings, and Ruellia simplex (Silva et al., 2020), for which there is an increase in the number of inflorescence as the proportion of carnaúba bagana volume is increased in the substrate.

It should be noted that the use of waste from agriculture can cause risks of environmental contamination, so it is necessary to give it a final destination. Thus, an option would be to generate alternative substrates, adopting ecologically sustainable and economically viable production systems.

In this context, the objective of this study was to evaluate the production of yellow passion fruit seedlings in substrates based on carnaúba palm bagana in different proportions with soil.

\section{Materials and Methods}

The experiment was conducted in a protected environment, in the experimental area of the Agrometeorological Station of Fortaleza, belonging to the Department of Agricultural Engineering, located at the Pici Campus, at the Federal University of Ceará, in Fortaleza, Ceará, Brazil. According to Köppen's classification, the climate of the site is Aw, characterized as rainy tropical, with high temperatures and prevailing rainfall in summer and autumn.

A completely randomized design was adopted, consisting of five treatments, with five replicates and three plants per experimental plot, totaling 75 passion fruit seedlings. The treatments consisted of substrates formulated from the combination of different proportions of carnaúba bagana (dry) and soil: Soil (100\%) + Carnaúba bagana (0\%); Soil (75\%) + Carnaúba bagana (25\%); Soil $(50 \%)$ + Carnaúba bagana (50\%); Soil (25\%) + Carnaúba bagana (75\%); and Soil (0\%) + Carnaúba bagana (100\%).

The soil used to compose the substrate was classified as Argissolo Vermelho-Amarelo (Ultisol). The chemical characteristics of the substrates used in the experiment can be observed in Table 1.

Table 1. Chemical composition of substrates: Soil (100\%) + Carnaúba bagana (0\%); Soil (75\%) + Carnaúba bagana (25\%); Soil $(50 \%)+$ Carnaúba bagana (50\%); Soil $(25 \%)+$ Carnaúba bagana (75\%); Soil (0\%) + Carnaúba bagana (100\%).

\begin{tabular}{|c|c|c|c|c|c|}
\hline Characteristics & S100 & S75CB25 & S50CB50 & S25CB75 & CB100 \\
\hline $\mathrm{pH}$ (water) & 5.8 & 4.8 & 4.7 & 4.6 & 4.7 \\
\hline $\mathrm{P}\left(\mathrm{mg} \mathrm{kg}^{-1}\right)^{*}$ & 5 & 8 & 15 & 26 & 102 \\
\hline $\mathrm{Ca}\left(\mathrm{cmol}_{\mathrm{c}} \mathrm{kg}^{-1}\right)$ & 0.5 & 1.9 & 3.5 & 5 & 26.8 \\
\hline $\mathrm{Mg}\left(\mathrm{cmol}_{\mathrm{c}} \mathrm{kg}^{-1}\right)$ & 1.4 & 1.1 & 2.5 & 1.5 & 14.7 \\
\hline $\mathrm{Na}\left(\mathrm{cmol}_{\mathrm{c}} \mathrm{kg}^{-1}\right)$ & 0.04 & 0.04 & 0.11 & 0.07 & 1.15 \\
\hline $\mathrm{K}\left(\mathrm{cmol}_{\mathrm{c}} \mathrm{kg}^{-1}\right)$ & 0.1 & 0.21 & 0.46 & 0.54 & 3.42 \\
\hline $\mathrm{H}+\mathrm{Al}\left(\mathrm{cmol}_{\mathrm{c}} \mathrm{kg}^{-1}\right)$ & 1.32 & 4.62 & 11.39 & 12.05 & 55.77 \\
\hline $\mathrm{Al}\left(\mathrm{cmol}_{\mathrm{c}} \mathrm{kg}^{-1}\right)$ & 0.15 & 0.45 & 0.7 & 0.7 & 2.9 \\
\hline $\mathrm{SB}\left(\mathrm{cmol}_{\mathrm{c}} \mathrm{kg}^{-1}\right)$ & 2 & 3.3 & 6.6 & 7.1 & 46.1 \\
\hline $\mathrm{CEC}\left(\mathrm{cmol}_{\mathrm{C}} \mathrm{kg}^{-1}\right)$ & 3.4 & 7.9 & 18 & 19.2 & 101.8 \\
\hline $\mathrm{V}(\%)$ & 61 & 41 & 37 & 37 & 45 \\
\hline $\mathrm{OM}\left(\mathrm{g} \mathrm{kg}^{-1}\right)$ & 4.55 & 17.27 & 34.55 & 64.13 & 333.08 \\
\hline $\mathrm{N}\left(\mathrm{g} \mathrm{kg}^{-1}\right)$ & 0.26 & 1.12 & 2.35 & 4.26 & 24.1 \\
\hline$E C\left(\mathrm{dS} \mathrm{m}^{-1}\right)$ & 0.26 & 0.91 & 1.66 & 2.04 & 2.25 \\
\hline
\end{tabular}

${ }^{*}$ Extracted by method Mehlich 1; SB: Sum of exchangeable bases; CEC: Cation exchange capacity at pH 7.0; V: Base saturation; OM: Organic matter; EC: Electric conductivity. 
The seedlings were produced using yellow passion fruit seeds (Topseed ${ }^{\circ}$ ), sowing five seeds in each experimental unit. Polyethylene bags with dimensions of $12-20 \mathrm{~cm}$, with 1.5 $\mathrm{dm}^{3}$ of volume, were filled with the substrates corresponding to the respective treatments and kept in a screen-protected environment with a $50 \%$ shade net.

The seedlings were manually irrigated every day by the weighing method, applying the volume of water evapotranspired on the previous day, in order to keep the substrate at its field capacity at the time of irrigation. At 15 days after emergence (DAE), thinning was performed, keeping only the most vigorous plant in each experimental unit.

At $45 \mathrm{DAE}$, between 8 and $11 \mathrm{~h}$, the net photosynthesis rate $\left(A-\mu m o l \mathrm{CO}_{2} \mathrm{~m}^{-2} \mathrm{~s}^{-1}\right)$ was evaluated using the IRGA device, whose reading was performed on fully expanded leaves of the plant.

At $60 \mathrm{DAE}$, the seedlings were evaluated for: height $(\mathrm{cm})$, determined from the plant collar to the last expanded leaf; stem diameter $(\mathrm{mm})$, measured at a distance of $2 \mathrm{~cm}$ from the substrate with a digital caliper; number of expanded leaves, by direct counting; and leaf area $\left(\mathrm{cm}^{2}\right)$, determined by a non-destructive method, based on leaf dimensions (length and width). After measurements of the growth variables, the plants were divided into shoots and root system, washed under running water, then with a solution of deionized water and neutral detergent $(0.1 \% \mathrm{v} / \mathrm{v})$ and then in deionized water again.

After obtaining these data, the plants were placed in paper bags properly identified, dried in a forced air circulation oven at $65 \stackrel{\circ}{\circ} \mathrm{C}$ until reaching constant mass, and weighed on an analytical scale to obtain shoot dry matter, root dry matter and total dry matter.

From the data obtained, the Dickson quality index (DQI) was calculated using Equation 1 (Dickson et al., 1960).

$$
\mathrm{DQI}=\frac{\operatorname{TDM}(\mathrm{g})}{\frac{\mathrm{PH}(\mathrm{cm})}{\mathrm{SD}(\mathrm{mm})}+\frac{\mathrm{SDM}(\mathrm{g})}{\mathrm{RDM}(\mathrm{g})}}
$$

where: TDM: total dry matter; PH: plant height; SD: stem diameter; SDM: shoot dry matter; RDM: root dry matter.
After the determination of shoot dry matter, the material was ground in a Wiley-type mill, with an 1-mm-opening mesh, and then placed in identified containers and taken to the Soil Laboratory of the Federal University of Ceará, to determine the contents of macro and micronutrients, according to the methodology of Malavolta et al. (1997). These data obtained were used to calculate the accumulation of nutrients, obtained by multiplying the contents by the shoot dry matter production of the seedlings.

The results were subjected to analysis of variance by the $F$ test and, when there was significance, the treatment means were compared by Tukey test at $5 \%$ and $1 \%$ probability levels.

\section{Results and Discussion}

It was verified, from the results of the analysis of variance (Table 2), that the different proportions of carnaúba bagana (CB) and soil (S) significantly affected all variables analyzed.

For plant height, it was observed that the substrate S25CB75 stood out from the other treatments (Table 2), with superiority of $85.21 \%$ in comparison to the lowest mean found in substrate S1. This result may be related to the presence of organic matter in the composition of this substrate (Table 1 ). That is, although the amount is lower than in CB100, S25CB75 possibly promoted greater water retention and nutrient distribution to the seedlings from the soil solution to the roots and, consequently, greater vegetative growth (Taiz et al., 2017).

It should be noted that in the traditional production system, yellow passion fruit seedlings are taken to the field when they are about $30 \mathrm{~cm}$ tall (Miyake et al., 2017). This average value is lower than the results found in the present study, except for the data obtained with $S 100(13.51 \mathrm{~cm})$. Siqueira et al. (2020), evaluating alternative substrates for the production of yellow passion fruit seedlings, found values ranging from 3.9 to 26.7 $\mathrm{cm}$ at 60 DAS.

According to the results of stem diameter, the seedlings produced in the substrate S50CB50 obtained values higher than those of the other treatments, but statistically equal to those found in the substrates S25CB75 and CB100 (Table 2). The increase in stem diameter is the result of cell expansion,

Table 2. Biometric characteristics: plant height (PH), stem diameter (SD), number of leaves (NL), leaf area (LA), shoot dry matter (SDM), root dry matter (RDM), total dry matter (TDM), Dickson quality index (DQI) and photosynthesis (A) of yellow passion fruit seedlings subjected to different proportions of carnaúba bagana and soil at $60 \mathrm{DAE}$.

\begin{tabular}{|c|c|c|c|c|c|c|c|c|c|c|}
\hline \multirow{2}{*}{ Substrates } & \multirow{2}{*}{$\begin{array}{l}\text { Soil (S) + Bagana } \\
\text { (CB) (\%) }\end{array}$} & \multirow{2}{*}{$\begin{array}{l}\mathrm{PH} \\
(\mathrm{cm})\end{array}$} & \multirow{2}{*}{$\begin{array}{l}\text { SD } \\
(\mathrm{mm})\end{array}$} & \multirow{2}{*}{ NL } & \multirow{2}{*}{$\begin{array}{l}\text { LA } \\
\left(\mathrm{cm}^{2}\right)\end{array}$} & SDM & RDM & TDM & \multirow[t]{2}{*}{ DQI } & \multirow{2}{*}{$\underset{\left(\mu \mathrm{mol} \mathrm{m} \mathrm{m}^{-2} \mathrm{~s}^{-1}\right)}{\mathrm{A}}$} \\
\hline & & & & & & & (g) & & & \\
\hline S100 & $100+0$ & $13.51 \mathrm{c}$ & $2.31 \mathrm{c}$ & $7.33 d$ & $42.42 b$ & $0.64 d$ & $0.21 \mathrm{c}$ & $0.85 \mathrm{~d}$ & $0.10 \mathrm{~b}$ & $7.58 \mathrm{~b}$ \\
\hline S75CB25 & $75+25$ & $31.80 c$ & $3.94 b$ & $9.40 c$ & $110.91 a$ & $2.95 c$ & $0.70 b$ & $3.65 c$ & $0.27 a$ & $8.55 a b$ \\
\hline S50CB50 & $50+50$ & $60.33 b$ & $4.63 a$ & $10.86 b c$ & $122.98 \mathrm{a}$ & $4.62 \mathrm{~b}$ & $1.03 a$ & $5.66 \mathrm{~b}$ & $0.33 a$ & $8.05 a b$ \\
\hline S25CB75 & $25+75$ & $91.33 a$ & 4.36ab & $13.46 a$ & $125.06 a$ & $6.25 a$ & $1.06 a$ & $7.32 a$ & $0.30 a$ & $10.03 a$ \\
\hline CB100 & $0+100$ & $68.73 b$ & $4.37 a b$ & 12.26ab & $116.47 a$ & $5.67 a$ & $0.76 \mathrm{~b}$ & 6.43ab & $0.28 a$ & $9.84 a$ \\
\hline Test $\mathrm{F}$ & & $4723.98 * *$ & $4.34^{* *}$ & $44.91 * *$ & $599.68 * *$ & $25.81^{* *}$ & $0.59 * *$ & $33.32^{* *}$ & $0.04 * *$ & $5.92 * *$ \\
\hline MSD & & 20.04 & 0.44 & 1.52 & 26.35 & 0.93 & 0.25 & 1.09 & 0.07 & 2.16 \\
\hline CV (\%) & & 19.89 & 5.99 & 7.53 & 13.42 & 12.29 & 17.84 & 12.03 & 15.95 & 12.98 \\
\hline
\end{tabular}

CV (\%): Coefficient of variation; MSD: Minimum significant difference; *Significant by $\mathrm{F}$ test at $5 \%$; Significant by $\mathrm{F}$ test at $1 \%$; ns = not significant. The means followed by the same letter in the column do not differ statistically from each other by the Tukey test $(p \geq 0,05)$. 
which can be favored by the presence of humic substances contained in the organic matter of S50CB50, S25CB75 and CB100, respectively. It is worth mentioning that seedlings with high value of stem diameter (for the present study conditions) indicate that there will be a good rate of survival after planting. This result is an indicator of the rates of net assimilation of photosynthesis products (Marana et al., 2015).

Similar results were found by Castro et al. (2016) when using the proportion of $60 \% \mathrm{CB}+40 \% \mathrm{~S}$ (Latossolo Vermelho Amarelo - Oxisol) for Enterolobium contortisiliquum seedlings. These same authors also verified a significant increase in stem diameter, similar to the mean values of this study.

The mean values found reveal that for the number of leaves there was statistical similarity between substrates S25CB75 and CB100 (Table 2). The same trend was observed by Araújo et al. (2017) in 'paricá' seedlings, which showed a significant increase in the number of leaves with the addition of $C B$ to the substrate. Similarly, the results of the present study are consistent with those reported by Siqueira et al. (2020), who found similar means for the number of leaves in yellow passion fruit seedlings.

Table 2 shows that CB, exception for S100, influenced leaf area when combined with $S$, regardless of its proportion in the composition of the substrates, which did not differ statistically from each other. The positive effect of $\mathrm{CB}$ may be related to its chemical characteristics, especially the amounts of potassium and nitrogen. Nomura et al. (2012) stated that the larger the leaf area, the better the rate of seedling survival in the field, because leaves are the structures responsible for capturing solar energy and producing organic material through photosynthesis.

For shoot dry matter, the substrate that promoted the best result was S25CB75, which was statistically equal to CB100 (Table 2). The increase in shoot dry matter can be explained by the higher $\mathrm{N}$ and $\mathrm{P}$ contents found in the compositions of substrates with $C B$ above $50 \%$, reinforcing the claim of Araújo et al. (2017), who stated that CB increases fertility and improves the physical properties of the substrates, promoting better seedling development.

Similar results were observed in the production of 'tamboril' seedlings by Araújo et al. (2016), who found that the substrates with higher proportion of $C B$ led to higher SDM. Sousa et al. (2020), working with CB in the formulation of substrates for 'açaí' seedlings, verified that the treatment containing 60 and $80 \% \mathrm{CB}$, plus $\mathrm{S}$, stood out from the others for this variable.

Seedlings that had the highest means of root dry matter (RDM) were those grown in the substrates S50CB50 and S25CB75. The substrate without CB in the composition (S100) led to the lowest mean of RDM. This result can be associated with the phosphorus and calcium levels present in these substrate proportions (Table 1), as well as the amount of organic matter, which improves the physical properties of the substrates, resulting in greater root development (Araújo et al., 2017; Miyake et al., 2017).
Results opposite to that of this study were found by Silva et al. (2020), who evaluated the effect of substrates based on CB $(40,60,80$ and $100 \%$ CB $+60,40,20$ and $0 \% S$, respectively) on the production of Ruellia simplex seedlings through vegetative propagation and observed that there was no significant difference for the values of root dry matter.

For total dry matter, the treatments S25CB75 and CB100 did not differ statistically from each other, with mean values of $7.32 \mathrm{~g}$ and $6.43 \mathrm{~g}$, respectively (Table 2). Results similar to those of the present study were obtained by Araújo et al. (2016), who noted that increasing proportions of CB-based organic residues in substrate composition contributed to better development and accumulation of TDM. Similarly, Silva et al. (2020) also found that treatments with a higher proportion of $\mathrm{CB}$ obtained higher TDM in Ruellia simplex seedlings.

Regarding Dickson quality index (DQI), except for S100, the other substrates were statistically similar. Seedlings produced without the addition of $C B$ obtained the lowest means for this variable. Thus, it is possible to infer that $C B$ favored the quality of yellow passion fruit seedlings, in its different proportions, when compared to the $S$ employed alone (Table 2). These results are even more evident by the fact that only the substrate with absence of $C B$ did not reach the minimum standard value for the DQI of the seedlings, which is 0.20 , as recommended by Hunt (1990).

It is worth remembering that the morphological parameters and relationships used for quality assessment should not be used alone for classifying the quality standard of seedlings, in order not to take the risk of selecting taller, but weak seedlings, discarding the shortest ones, but with greater vigor (Marana et al., 2015).

The results obtained in the present study were higher than those obtained by Silva et al. (2019), who observed DQI values ranging from 0.02 to 0.08 in yellow passion fruit seedlings, in substrates with different sources of organic matter (bovine manure and coffee residue). On the other hand, Berilli et al. (2018) obtained DQI values similar to that of the present study when evaluating the effect of foliar fertilization with liquid tannery sludge on yellow passion fruit seedlings.

For photosynthesis (A), except for $\mathrm{S} 100$, all other substrates did not differ statistically from each other (Table 2). Possibly, this result is related to the amounts of nitrogen, phosphorus and potassium present in these substrates (Table 1), since $\mathrm{N}$ serves as a constituent of many plant cell components, including chlorophyll, besides activating many enzymes involved in photosynthesis; phosphorus stimulates enzymatic activity and RuBisCO synthesis, favoring the assimilation of $\mathrm{CO}_{2}$, which favors photosynthesis; and $\mathrm{K}$ regulates stomatal opening (Taiz et al., 2017).

The results for macronutrient accumulation are shown in Table 3, where it is possible to observe that the different proportions of CB plus $S$ significantly affected all variables analyzed.

Table 3 shows that S25CB75 and CB100 led to higher $\mathrm{N}$ accumulation, resulting from the higher dry biomass 
Table 3. Accumulation of macronutrients in the shoots of yellow passion fruit seedlings, subjected to different proportions of carnaúba bagana plus soil.

\begin{tabular}{|c|c|c|c|c|c|c|}
\hline \multirow{2}{*}{ Substrates } & \multirow{2}{*}{$\begin{array}{c}\text { Soil (S) + Bagana (CB) } \\
(\%)\end{array}$} & $\mathbf{N}$ & $\mathbf{P}$ & $\mathbf{K}$ & $\mathrm{Ca}$ & $\mathrm{Mg}$ \\
\hline & & \multicolumn{5}{|c|}{ (g plant $\left.^{-1}\right)$} \\
\hline S100 & $100+0$ & $7.04 d$ & $1.16 \mathrm{~d}$ & $4.30 c$ & $3.64 d$ & $1.32 \mathrm{c}$ \\
\hline S75CB25 & $75+25$ & $26.35 c$ & $3.03 b c$ & $16.81 b$ & $17.03 c$ & $5.99 b$ \\
\hline S50CB50 & $50+50$ & $47.58 b$ & $4.39 a$ & $26.54 a$ & $25.20 \mathrm{~b}$ & $9.55 b$ \\
\hline S25CB75 & $25+75$ & $71.65 a$ & 4.17ab & $29.48 a$ & $33.24 a$ & $14.83 a$ \\
\hline CB100 & $0+100$ & $72.79 a$ & $2.72 \mathrm{c}$ & $30.53 a$ & $34.15 a$ & $15.06 a$ \\
\hline Test F & & 4097.73* & $8.41^{* *}$ & $610.68 * *$ & $804.93 * *$ & $173.04 * *$ \\
\hline MSD & & 16.35 & 1.22 & 7.08 & 7.87 & 3.75 \\
\hline CV (\%) & & 19.13 & 20.81 & 17.36 & 18.34 & 21.18 \\
\hline
\end{tabular}

CV (\%): Coefficient of variation; MSD: Minimum significant difference; *Significant by F test at $5 \%$; Significant by F test at $1 \%$; ns = not significant. The means followed by the same letter in the column do not differ statistically from each other by the Tukey test $(p \geq 0,05)$.

production in these plants. This result may also be related to the greater availability of this nutrient in the substrate (Table 1), which denotes that high concentrations of $\mathrm{N}$ in organic residues may be an indication that these may act as a source of nitrogen for plants, such as CB.

The results obtained in the present study are in accordance with those of Albano et al. (2017), who also verified a positive effect on the amounts of $\mathrm{N}$ in the plant tissue of 'Formosa' papaya (Carica papaya L.) seedlings grown in substrate based on semi-decomposed carnaúba palm residue.

Regarding $\mathrm{P}$ accumulation (Table 3 ), the treatments S50CB50 and S25CB75 differed statically from the other treatments. The greater accumulation of this macronutrient in these substrates is possibly related to the synergistic effect between magnesium and phosphorus ions. In papaya seedlings grown in semi-decomposed CB residue, Albano et al. (2017) also verified the positive influence of the substrate on the P content in the shoots of the seedlings.

The highest potassium accumulations (Table 3) were obtained in treatments with highest proportions of $C B$ (S50CB50, S25CB75 and CB100), which may be linked to the presence of the nutrient in the substrates. These results can also be explained by relating the accumulation of $\mathrm{K}$ in plant tissue to the dry matter production in these plants (Table 2).

Results consistent with those of the present study were reported by Oliveira et al. (2018), who analyzed potential organic fertilizers and verified through the analysis of the chemical composition the capacity of $\mathrm{CB}$ to contribute to plant nutrition and, consequently, to the supply of $K$ to plants. Similar results were also obtained by Albano et al. (2017) in papaya seedlings, in which nutrient content was significantly influenced by the substrates based on carnaúba palm residues.

Seedlings grown in the substrates S25CB75 and CB100 showed higher calcium accumulation when compared to those of the other treatments (Table 3). This is possibly related to the increasing content of $\mathrm{Ca}$ in the substrate (Table 1).

Ca was the second most accumulated macronutrient in the shoots of the seedlings, which may have occurred as a result of its low mobility in the plant (Fernandes et al., 2018). Similar results were found by Barros et al. (2013) in yellow passion fruit seedlings cultivated in substrates with composts of green manure and foliar biofertilizer, in which Ca was also verified in this order of accumulation.

The mean values reveal that the substrates S25CB75 and CB100 were statistically superior to the others, in relation to $\mathrm{Mg}$ accumulation in the shoots of the seedlings (Table 3 ). Possibly, the $P$ present in these substrates contributed to higher accumulations of $\mathrm{Mg}$, evidencing the synergistic effect among these essential elements (Prado, 2020), in addition to the higher dry matter production of these plants.

The accumulation of macronutrients in the shoots of passion fruit seedlings occurred in the following descending order: $\mathrm{N}>\mathrm{Ca}>\mathrm{K}>\mathrm{Mg}>\mathrm{P}$. This result differs from that found by Barros et al. (2013) when investigating the use of Supermagro biofertilizer in yellow passion fruit seedlings cultivated in a protected environment; these same authors observed the following order for nutrient accumulation: $\mathrm{K}>\mathrm{Ca}>\mathrm{N}>\mathrm{Mg}>\mathrm{P}$. The results of the present study also differ from those found by Borges \& Lima (2009) for the amounts of nutrients absorbed by the yellow passion fruit in adult phase, including fruits, with the following order in nutrient accumulation: $\mathrm{N}>\mathrm{K}>\mathrm{Ca}>$ $\mathrm{P}>\mathrm{Mg}$. This result indicates that the accumulation of mineral nutrients in the plant depends on its stage of development as well as morphological and physiological characteristics, as reported by Marschner (2012). For the accumulation of micronutrients, it was found that all evaluated elements were significantly influenced by the treatments (Table 4).

The substrates S50CB50 and S25CB75 differed statistically from the other treatments, leading to higher accumulation of iron in the shoots (Table 4). It is worth pointing out that of micronutrients, $\mathrm{Fe}$ is one of the most absorbed by yellow passion fruit (Haag et al., 1973). This nutrient has low mobility in the tissues, which explains its high contents in the plants evaluated (Fernandes et al., 2018).

The present study corroborates the information provided by Nascimento \& Freire (2020) according to which iron was one of the most accumulated micronutrients in the leaf tissue of yellow passion fruit. Contrary to the present study, Lima et al. (2009) describe that substrates with CB did not have a positive effect on the Fe element in soursop seedlings.

The data contained in Table 4 show that only S25CB75 was statistically superior to the other substrates in terms of copper accumulation. The high accumulation of $\mathrm{Cu}$ in leaf tissue 
Table 4. Accumulation of micronutrients in the shoots of yellow passion fruit seedlings, subjected to different proportions of carnaúba bagana plus soil.

\begin{tabular}{|c|c|c|c|c|c|}
\hline \multirow{2}{*}{ Substrates } & \multirow{2}{*}{$\begin{array}{c}\text { Solo (S) + Bagana (CB) } \\
(\%)\end{array}$} & Fe & $\mathrm{Cu}$ & $\mathrm{Zn}$ & $\mathrm{Mn}$ \\
\hline & & \multicolumn{4}{|c|}{ (mg plant ${ }^{-1}$ ) } \\
\hline S100 & $100+0$ & $132 c$ & $5 c$ & $23 d$ & $5 c$ \\
\hline S75CB25 & $75+25$ & $476 b$ & $15 b$ & $80 c$ & $59 c$ \\
\hline S25CB75 & $25+75$ & $967 a$ & $28 a$ & $179 a b$ & $1011 b$ \\
\hline CB100 & $0+100$ & $435 b$ & $14 b$ & $208 a$ & 1693a \\
\hline CV (\%) & & 30.34 & 26.03 & 27.57 & 36.91 \\
\hline
\end{tabular}

CV (\%): Coefficient of variation; MSD: Minimum significant difference; $*$ Significant by $\mathrm{F}$ test at $5 \%$; Significant by $\mathrm{F}$ test at $1 \%$; $\mathrm{ns}=$ not significant. The means followed by the same letter in the column do not differ statistically from each other by the Tukey test $(p \geq 0,05)$.

can be justified by the predominant acidity in this substrate composition.

In line with the present study, Nascimento \& Freire (2020) state that the higher accumulations of copper in the leaf tissue of yellow passion fruit seedlings suggest greater requirement of this species to allocate the element in its tissues. Lima et al. (2009) found lower Cu content in soursop leaves in substrates with the presence of $C B$.

Treatments with the highest percentage of CB (S25CB75 and $\mathrm{CB100}$ ) were statistically superior in relation to zinc accumulation in the shoots of the plants (Table 4). These results may be related to the synergism between zinc and nitrogen in their processes of absorption (Cessa et al., 2017). Results similar to those of the present study were found by Nascimento \& Freire (2020), who observed higher accumulation of zinc in yellow passion fruit seedlings.

Table 4 shows that the increase in $C B$ in the treatments increased the accumulation of $\mathrm{Mn}$ in leaf tissue, with the substrate CB100 being statistically superior to the others. In this context, Fernandes et al. (2018) point out that, under the condition of good supply of $\mathrm{Mn}$, the leaves accumulate high concentrations of the element, as the age of the plant progresses, and a small portion of the nutrient is translocated from the old leaves to the young ones in growth.

The accumulation of micronutrients in the shoots of yellow passion fruit followed the following descending order: $\mathrm{Mn}$ $>\mathrm{Fe}>\mathrm{Zn}>\mathrm{Cu}$. This accumulation order is in accordance with the result observed by Borges \& Lima (2009) for the amount of nutrients absorbed by the whole plant, including fruits of yellow passion fruit plants at 370 days of age. These results denote that the accumulation of micronutrients by passion fruit seedlings follows the same order of absorption as that of adult plants.

\section{Conclusions}

The presence of carnaúba bagana $(C B)$, regardless of its proportion in the substrate, leads to better results in photosynthesis and DQI in yellow passion fruit seedlings.

The best morphological responses were obtained with proportions greater than $50 \%$ of carnaúba bagana (CB), which also led to greater accumulation of nutrients in the shoots of yellow passion fruit.

\section{Acknowledgments}

To the National Council for Scientific and Technological Development (CNPq).

\section{Compliance with Ethical Standards}

Author contributions: Conceptualization: AMM; Data curation: AMM; Formal analysis: AMM, FBSJ; Project administration: WN, GGS; Supervision: WN, GGS; Resources: GGS; Visualization: AMM, FBSJ.

Conflict of interest: The authors declare that there is no conflict of interest (personal or financial) that may influence the article.

Financing source: National Council for Scientific and Technological Development (CNPq).

\section{Literature Cited}

Albano, F.G.; Cavalcante, I.H.L.; Machado, J. S.; Lacerda, C. F. de; Silva, E.R. da; Sousa, H.G. de. New substrate containing agroindustrial carnauba residue for production of papaya under foliar fertilization. Revista Brasileira de Engenharia Agrícola e Ambiental, v.21, n.2, p.128-133, 2017. https://doi. org/10.1590/1807-1929/agriambi.v21n2p128-133.

Araújo, E.F.; Aguiar, A.S.; Arauco, A.M.S.; Gonçalves, E.O.; Almeida, K.N.S. de. Crescimento e qualidade de mudas de paricá produzidas em substratos à base de resíduos orgânicos. Nativa, v.5, n.1, p.16-23, 2017. https://doi.org/10.5935/2318-7670. v05n01a03.

Araújo, E.F.; Arauco, A.M.S.; Lacerda, J.J.J.; Ratke, R.F.; Medeiros, J.C. Crescimento e balanço nutricional de mudas de Enterolobium contortsiliquum com aplicação de substratos orgânicos e água residuária. Pesquisa Florestal Brasileira, v.36, n.86, p.169-177, 2016. https://doi.org/10.4336/2016.pfb.36.86.1135.

Barros, C.M.B.; Müller, M.M.L.; Botelho, R.V.; Michalovicz, L.; Vicensi, M.; Nascimento, R. do. Substratos com compostos de adubos verdes e biofertilizante via foliar na formação de mudas de maracujazeiro-amarelo. Semina: Ciências Agrárias, v.34, n.6, p.2575-2587, 2013. https://doi.org/10.5433/1679$0359.2013 v 34 n 6 p 2575$ 
Berilli, S.S.; Pereira, L.C.; Pinheiro, A.P.B.; Cazaroti, E.P.F.; Sales, R.A.; Lima, C.F. Adubação foliar com lodo de curtume líquido no desenvolvimento e qualidade de mudas de maracujá-amarelo. Revista Brasileira de Agricultura Irrigada, v.12, n.2, p.2477, 2018. https://doi.org/10.7127/rbai.v12n200762.

Borges, A. L.; Lima, A. de A. Maracujazeiro. In: Crisóstomo, L. A.; Naumov, A. (Orgs.). Adubando para alta produtividade e qualidade: fruteiras tropicais do Brasil. Fortaleza: Embrapa Agroindústria Tropical, 2009. p. 166-181.

Castro, V. C. de; Fernandes, M. M.; Fernandes, M.R. de M.; Nóbrega, R.S.A. Avaliação de diferentes substratos orgânicos para mudas de Enterolobium contortisiliquum em uma área desertificada. Revista Agrogeoambiental, v.8, n.3, p.101-109, 2016. https://doi. org/10.18406/2316-1817v8n32016884.

Cessa, R. M. A.; Lima, L. S. F.; Melo, E. P. de. Pulverização foliar com nitrogênio e zinco em milho (Zea mays L.) "safrinha" em Confresa (MT). Revista Agrogeoambiental, v.9, n.1, p.55-64, 2017. https:// doi.org/10.18406/2316-1817v9n12017869.

Dickson, A.; Leaf, A.L.; Hosner, J.F. Quality appraisal of white spruce and white pine seedling stock in nurseries. The Forest Chronicle, v.36, n.1, p.10-13, 1960. https://doi.org/10.5558/tfc36010-1.

Fernandes, M.S.; Souza, S.R. de; Santos, L.A. Nutrição mineral de plantas. Viçosa: Sociedade Brasileira de Ciência do Solo, 2018. $670 p$.

Haag, H.P.; Oliveira, G.D. de; Borducchi, A.S.; Sarruge, J.R. Absorção de nutrientes por duas variedades de maracujá. Anais da ESALQ, v.30, p.267-279, 1973. https://doi.org/10.1590/S007112761973000100020.

Hunt, G.A. Effect of styroblock design and copper treatmenton morphologyof conifer seedlings. In: Rose, R.; Campbell, S.J.; Landis, T. D. (Eds.). Target seedling symposium: proceedings, combined meeting of the western forest nursery associations, general technical. Roseburg: Association United States Departament of Agriculture, 1990. p. 218-222.

Instituto Brasileiro de Geografia e Estatística - IBGE. Produção agrícola municipal 2019. Rio de Janeiro. https://sidra.ibge.gov. br/tabela/5457\#resultado. 22 Oct. 2020.

Junghans, T.G.; Jesus, O.N. de. Maracujá: do cultivo à comercialização. Brasília: Embrapa, 2017. 341p.

Lima, R. de L.S. de; Weber, O.B.; Pereira, W.E.; Correia, D.; Sofiatti, V.; Brandão, Z.N.; Ferreira, G.B. Crescimento e teores de nutrientes em mudas de gravioleira cultivadas em seis substratos. Engenharia Ambiental, v.6, n.3, p.594-606, 2009. https://ainfo. cnptia.embrapa.br/digital/bitstream/CNPAT-2010/11807/1/ PC09020.pdf. 15 Dec. 2020.

Malavolta, E.; Vitti, G.C.; Oliveira, S. A. Avaliação do estado nutricional das plantas: Princípios e aplicações. Piracicaba: Potafos, 1997. $319 \mathrm{p}$.

Marana, J.P.; Miglioranza, É.; Fonseca, É. de P. Qualidade de mudas de jaracatiá submetidas a diferentes períodos de sombreamento em viveiro. Revista Árvore, v.39, n.2, p.275-282, 2015. https:// doi.org/10.1590/0100-67622015000200007.

Marschner, P. Marschner's mineral nutrition of higher plants. 3.ed. San Diego: Academic Press, 2012. 672p.
Miyake, R.T.M.; Creste, J.E.; Narita, N.; Guerra, W.E.X. Substrato e adubação nitrogenada na produção de mudas de maracujazeiro amarelo em condições protegidas. Colloquium Agrariae, v.13, n.1, p.57-65, 2017. https://revistas.unoeste.br/index.php/ca/ article/view/1453. 15 Dec. 2020.

Nascimento, G. dos S.; Freire, J.L. de O. Atributos de crescimento e concentração de micronutrientes em mudas de maracujazeiros irrigadas com águas salinas e uso de UOV. Brazilian Journal of Development, v.6, n.7, p.45515-45527, 2020. https://doi. org/10.34117/bjdv6n7-248.

Natale, W.; Lima Neto, A.J. de; Rozane, D.E., Parent, L.E.; Corrêa, M.C. de M. Evolução da nutrição mineral na formação de porta-enxertos e mudas de frutiferas. Revista Brasileira de Fruticultura, v.40, n.6, p.1-15, 2018. https://doi.org/10.1590/0100-29452018133.

Natale, W.; Rozane, D.E.; Parent, L.E.; Parent, S.É. Acidez do solo e calagem em pomares de frutiferas tropicais. Revista Brasileira de Fruticultura, v.34, n.4, p.1294-1306, 2012. https://doi. org/10.1590/S0100-29452012000400041.

Nomura, E.S.; Damatto Junior, E R.; Fuzitani, E.J.; Saes, L.A.; Jensen, E. Aclimatização de mudas micropropagadas de bananeira 'Grand Naine' com aplicação de biofertilizantes em duas estações do ano. Revista Ceres, v.59, n.4, p.518-529, 2012. https://doi. org/10.1590/S0034-737X2012000400013.

Oliveira, L.S.; Costa, M.C.G.; Souza, H. de A.; Blum, J.; Albuquerque, G.H. da S.; Abreu, M.G.P. de; Maia, D. de S. Characterization of organic wastes and effects of their application on the soil. Journal of Agricultural Science, v.10, n.6, p.291-298, 2018. https://doi. org/10.5539/jas.v10n6p291.

Prado, R. de M. Nutrição de plantas. São Paulo: Editora UNESP, 2020. $416 p$.

Silva, L.G.F.; Sales, R.A.; Rossini, F.P.; Vitória, Y.T. da; Berilli, S. da S. Emergência e desenvolvimento de plântulas de maracujáamarelo em diferentes substratos. Energia na Agricultura, v.34, n.1, p.18-27, 2019. https://doi.org/10.17224/ EnergAgric.2019v34n01p18-27.

Silva, T.F.; Lopes, K.A. do L.; Santos, J.F. dos; Sousa, A.P. de A.; AlbanoMachado, F.G.; Silva-Matos, R.R.S. da. Ruellia simplex cuttings propagation produced on carnauba waste substrate. Revista Agro@mbiente On-line, v.14, p.1-11, 2020. https://doi. org/10.18227/1982-8470ragro.v14i0.6185.

Siqueira, R.H. da S.; Monteiro Neto, J.L.L.; Chagas, E.A.; Martins, S.A.; Oliveira, A.H.C. de; Silva, E.S. da. Seleção de substratos para a produção de mudas de maracujazeiroamarelo em Roraima. Revista de Ciências Agrárias, v.63, p.19, 2020. http://200.129.150.26/index.php/ajaes/article/ view/3242/1599. 15 Dec. 2020.

Sousa, M. de O.; Matos, R.R.S. da S.; Cardoso, J.P.S.; Cordeiro, K.V.; Barbosa, L.M. de P.; Santos, J.F. dos; Oliveira, A.R.F.; Machado, F.G.A.; Costa, N.A.; Oliveira, M.M.T. de. Bagana de carnaúba como substrato na produção de mudas de açaí cultivar BRS-Pará. Revista Ibero-Americana de Ciências Ambientais, v.11, n.5, p.113-122, 2020. https://doi.org/10.6008/CBPC2179-6858.2020.005.0012.

Taiz, L.;Zeiger. E.; Møller, I.M.; Murphy, A. Fisiologia e desenvolvimento vegetal. Porto Alegre: Artmed, 2017. 858p. 